\title{
Assessing English Language Needs through the Lens of ESP - EFL Students' Perspectives
}

\author{
Anik Kusnawati \\ State Polytechnic of Malang, Malang, Indonesia \\ anik.kusnawati@polinema.ac.id
}

\begin{abstract}
ESP students are one of stakeholder informants in needs analysis. This paper reports ESP-EFL students' perspectives on their target and present English needs by seeking information about their reasons and decisions in determining those needs. Thematic analysis using a conceptual framework of target and present situation analysis was used to analyze the qualitative aspect of the data from focus group interviews with a total of 18 accounting students in a tertiary vocational institution. The results of the study revealed that the students' target communicative needs were English conversational skills for social interactions; whereas, their occupational disciplinary need was accounting terminology mastery. Nevertheless, in the Indonesian EFL context with limited uses of English, the analysis provided evidence that students had limited knowledge of their target needs. The reports on their learning needs and wants for the more sequential design of English courses pertained to excessive grammar provision and improvement of their limited knowledge of English accounting terminology provided insights into the type of language exposure they had received. Furthermore, they also reveal the way students wanted to achieve their target needs. This study contributed to our understanding of their knowledge of English language use in the target occupational domain and the factors that exerted greater influence on their determination of language skills and knowledge they needed.
\end{abstract}

Keywords: needs analysis, EFL context, students' perspectives

\section{INTRODUCTION}

Needs analysis is essential in English for specific purposes (ESP), especially for the design of ESP curriculum and teaching materials or the improvement of the existing curriculum/materials. In the contexts where English is used as a second or native language (ESL), needs analysis research has developed into two major areas, i.e. target situation analysis (TSA) and present situation analysis (PSA). TSA concentrates on studies of communicative tasks and events in the target discourse community (e.g. Cowling, 2007; Kassim \& Ali, 2010; Lehtonen \& Karjalainen, 2009; Pholsward, 1993) and has been predominantly intensified with research on specific language uses in academic and occupational domains as found in register/discourse/genre analyses (e.g. Evans, 2012; Gimenez, 2000; Sinclair, 1980; Swales 1990, 2004). It has contributed to rigorous text analysis (written or spoken) which addresses not only analysis of linguistic features and rhetorical structures of a target text, but also analysis of the social action underlying the construct of the text as found in the study of Flowerdew and Wan $(2006,2010)$. Such a text analysis of a genre has been introduced into ESP pedagogies. ESP courses have included authentic discipline-specific materials using genre analytical framework for text analysis (e.g. Bhatia, 1991; Henry, 2007; Yayli, 2011). Meanwhile, PSA covers studies of learners' present language deficiency and learning condition (e.g. Bacha \& Bahous, 2008; Edwards, 2000; Holliday, 1995). Even though it has been less well-developed compared to TSA, it has provided insight into learners' linguistic and conceptual problems in understanding their discipline-specific texts as perceived by content lecturers (Jackson, 2005) as well as learners' perceived language abilities and needs in an academic domain (Bacha \& Bahous, 2008).

On the contrary, in the contexts where English is used as a foreign language (EFL), even though students' needs for English have been connected with the demand for reading literature in English (e.g. Chia et al., 1999; Hamied, 2005; Huda, 1999), TSA has been less-well developed. In the context of Indonesia, the ability to read literature in English has become the primary goal of English for Academic Purposes (EAP); however, the target needs of academic reading have not been elaborated in detail. This means that the extent to which EAP students are required to read English academic texts is not clearly defined (Coleman, 1997). This condition becomes more complicated as textbooks in Bahasa Indonesia in every field are available, cheap and abundant, making the majority of university students prefer not to read English textbooks (Coleman, 1997; Sadtono, 2005). Furthermore, even though English textbooks are the major content of all book holdings in college and university libraries (Adyawardhani, 2003; Coleman cited in Nurweni \& Read, 1999), it is also less understood whether EAP students are really required to read English academic references by their subject teachers and whether such a requirement is discussed in their subject courses. These supported the fact that there is still no definite judgment on the expected level of learner performance in English academic reading. While the primary concern of academic reading is the content delivery (Brown, 2007), i.e. EFL learners learn English in order to learn a particular subject matter, the EAP courses have shown limited awareness of students' needs in academic reading in higher education. As such, the courses typically proceed with what had been set out 
in high schools, and thus they are usually short and have been less developed.

In addition, even though a few numbers of needs analyses have been developed in some universities in Indonesia, they still focused on understanding learners' learning needs and wants (see e.g. Djiwandono, 2008; Jubhari, 2006; Rohayati, Coleman, \& Hardjanto, 1997). Furthermore, other scholars claimed the necessity of needs analysis, but they still discussed it at the conceptual levels (see e.g. Harsono, 2007; Madya, 2003; Riyandari, 2003; Sujana, 2006). While these phenomena have provided evidence that analyses of target needs for English education in tertiary levels in Indonesia have been underdeveloped, how EFL learners understand their target and learning needs regarding their particular discipline is still scarcely investigated. In such condition, this article reports part of a Ph.D. study that looked into the learners' perspectives of their English needs and their practices of a needs analysis by looking into their reasons and decisions in determining their needs. Such a study was necessary to provide insight into the extent to which they understood their needs as Long (2005) argues that as learners have no working experience, they know little about target workplace tasks and the language involved to function successfully in target discourse domains (p. 20). This article is expected to provide evidence for the necessity to conduct target needs analysis in the future.

\section{METHODS}

This paper reports the qualitative case study data from focus group interviews with eighteen students in their final year of study in the Accounting Department of a tertiary vocational institution. Focus group interview was selected as it could provide access to the students' actual and relevant interactional experiences in learning English at the Department when they were provided a chance to spark off one another (Berg, 2009) in a permissive, non-judgmental environment of a group discussion (Krueger \& Casey, 2000). The 18 students were selected using purposive sampling strategy to get heterogeneous participants in terms of the levels of their English proficiency (from high to low). The purpose was not to compare the needs of the students of different levels of proficiency, but to examine the extent to which these heterogeneous students understand the relevance of ESP courses to accounting courses and their future employment. Each interview was conducted for approximately an hour and a half to two hours and the design of the questions was openended, thus students are allowed to respond according to their specific situations. There were four to five student participants in each group.

The data were analyzed by using a thematic approach. Braun's and Clarke's (2006) thematic analytic procedures were adopted as the researcher believes that while the data per se reveal is essential, the themes generated from the data epistemologically are not free from the researcher's theoretical conceptions on which this study focused. Thus, initial themes for framing inductive analysis were derived from the literature related to needs analyses of both target and present situation analyses (e.g. Belcher, 2006; Long, 2005; Swales, 1986). They comprised four major areas:

(1) Stakeholders involved in needs assessments.

(2) Sources used in needs assessments.

(3) Factors that affected the stakeholders' decision in needs assessments.

(4) Language needs to be elaborated into language skills and knowledge.

These areas corresponded to the main themes of the interview questions. However, the themes emerged from the data were essential and governed the major analysis that led to conclusion drawings. They were also to be compared and refined across different datasets for similarities and differences in order to allow the data to be viewed from different angles (Leech \& Onwuegbuzie, 2007, 2008) and to develop conclusions regarding the present needs assessment practices.

\section{RESULTS AND DISCUSSION}

The results of the study revealed that the students' pragmatic ways of analyzing their target needs (target situation analysis/TSA). They considered the importance of English conversational skills that they drew from the communication norm of their discourse community. They also conceived that understanding English accounting terminology was crucial. Their reports on their present situation analyses (PSA) showed that their analyses of their environment and learning needs were intended to achieve the preconceived target needs. These are presented in detail in the following discussion.

\subsection{TSA for communicative needs: Conversational skills and preconceptions of target workplace discourse}

The key findings of the students' analyses of target needs revealed that the majority of them identified the target needs broadly referring to the primacy of oral communicative competencies. The workplace English language use which they identified predominantly referred to conversational skills for social interactions with colleagues and communicative competence for presentations in business meetings. This interest was drawn from the belief that speaking was the most effective means of communication. This belief was also common in other EFL contexts such as in Jordan (Al-Jamal \& Al-Jamal, 2014), China (Zhang, 2009), and Thailand (Boonkit, 2010). In these contexts, the students' primary motivation to learn English was being able to speak English for social communication including communication with English native speakers. This motivation corresponded to other research findings in the Indonesian context (Djiwandono, 2008; Jubhari, 2006).

Nevertheless, this study added to our knowledge and understanding by providing information about the students' underlying reasons for determining the perceived target needs. They had inadequate information about workplace discourse. Their idea of social communications of the target situation was based on what they assumed to be the case from their mother tongue discourse community. They referred to the usual interaction norm "speaking" which they perceived as the most frequent and effective form of communication. This 
association with their social discourses was exemplified in the following extracts:

S1: [313] speaking is the most frequent (form of) communication... [316] Whatever (we communicate) the most effective is through speaking, so I think speaking (is the most important).

S3: [320] No difference, simply because speaking is the most frequent (pause), a communication skill that is most frequently used by people.

Other students expressed the primacy of speaking differently, but still focused on its function for communicating with people as represented by student $\mathrm{S} 16$ :

S16: [379] For me, speaking (is crucial) because we have to get along with people, they talk, we listen, and then reply, that's the most important...

As student S16 mentioned 'talk,' 'listen,' and 'reply,' he perceived that to get along with people, he needed to maintain two-way friendly communication. The students' identification of the social communication might be partly derived from their knowledge about communication keys, i.e. how they should communicate in social discourse. These suggested that these students examined their communicative needs based on the typical communication pattern in their social discourse. Their approach was pragmatic as they drew their English needs from the forms of communication they used every day and then associated them with the types of communication they might face in the workplace. Speaking and listening are dominant interaction norms in the mother-tongue communication, and similar to Long's (2005) findings, these learners have limited information about target workplace tasks and limited knowledge of the language involved in performing the workplace tasks.

\subsection{PSA for improving communicative needs: Desires to speak English accurately and fluently}

This study also found that the students wanted to improve their speaking accuracy and fluency. In discussing their English lectures and speaking tasks, they identified that communication breakdowns occurred during a group or class discussion when they did not know how to respond in English. This undermined their speaking confidence. Their concern was their inability to maintain continuous reciprocal communication which involved speaking and listening skills. Nevertheless, as a considerable number of them found that they were bored with the models of discussion used during their English lectures because the communication was one directional, the area of their concern which they thought had not been much developed was 'strategic competence' (Savignon, 2007) or knowledge of interaction patterns (Sayer, 2005) to improve their fluency. In the area of learning situation analysis, this provides insights into the necessity of understanding student-student classroom discourse to examine their effective participation in conversational exchanges
(Sayer, 2005). However, learning situation analysis has not interested scholars in English-speaking countries. Meanwhile, in EFL countries where students have no immediate need of oral communication, learner needs of strategy preferences might need to be emphasized (Nunan, 2001). This has not received much attention in the context of ESP pedagogy. This study contributes to our understanding of students' awareness of their learning process, communication breakdowns occurring during classroom speaking activities, and strategies that they perceived would help them improve their speaking fluency.

The students' analyses of their learning process also revealed environmental constraints that potentially inhibited their success in improving their speaking proficiency. For example, besides the inability to maintain two-way communication, some of them reported that they had no confidence to speak because of being afraid of making grammatical mistakes. Their stories of their learning experience in their secondary schools revealed that they had been much exposed to grammar teaching. When they joined the English courses at the Department, they found a significant shift in their English education, from the focus on grammar to the focus on speaking. These students acknowledged that this changed learning condition was a great challenge for them as they scarcely practiced speaking English in their previous education. This condition was more striking than before because they found limited uses of English for social interactions in their surroundings and limited exposures to English beyond listening to music and watching western films. Therefore, they found it hard to understand what they needed to do to improve their speaking competence. Drawing from their classroom speaking practices, they wanted to have more feedback with a grammatical focus to improve their speaking accuracy. Most of them wanted to improve their mastery of grammar in their productive skills. However, they wished grammar had been taught appropriately at the beginning of their program and did not expect that all the courses would predominantly discuss grammar in a manner similar to their previous education in secondary schools. Some students perceived that grammar was likely to be the focus of all the English courses as exemplified in the following extract:

S2: [41] ...in the first year (the English course) started with grammar, semester two writing, automatically related to grammar, right Mam? ..... [45] .....in the third year back to structure.

The students' report of their present needs added to our understanding of the comprehensive information they provided regarding their learning needs. Their learning experiences gave them insights into the learning problems they encountered, their learning context and priorities. In addition, their reports of their secondary and tertiary English education shed light on the existing gap associated with different educational orientations in these two institutions. The investigation into this gap is crucial to understand the areas of students' learning difficulties in the critically changed learning condition. 


\subsection{TSA and PSA for accounting needs: Desires to improve knowledge of English accounting terminology}

The findings from the students' analyses of their accounting needs revealed their focus on bilingual financial statements. The importance of these statements was evident for them as they found these statements on the Internet, in their work practice and their friends' information about a similar work practice. They perceived that knowledge of English accounts and being able to write financial statements in English were necessary for their future jobs. This study found that their focus on the terminology knowledge was heavily influenced by the difficulties they encountered in using the terminology. One student reported her difficulty in understanding an accounting process during her work practice because of her unfamiliarity with the English accounts. Similarly, some students acknowledged their unfamiliarity with the terminology used in accounting textbooks and got difficulties in dealing with these texts and case exercises which were presented in English. These students attributed their difficulties to the inadequacy and complication of learning English accounts in their accounting and ESP courses.

The students analyzed the inadequacy of learning English accounts based on the case study exercises they received from their accounting lecturers and their ESP courses. They perceived that aspects of their learning difficulties were attributed to the lecturers' instructional models. For example, they pointed out that case study exercises provided by the accounting lecturers did not adequately help them understand the terminology because there was limited information about what, how, and when the terminology was used. They also acknowledged that in their preparation for a business role play, the English lecturers had different ideas about appropriate uses of some terms related to budgeting. They believed that the English lecturers were not familiar with the terminologies used in the accounting discipline as shown in the following extract:

S15: [564] When we prepared a presentation and discussed the job description of an accounting manager, we used some (English) terms in accounting such as planning budget, the (English) lecturer did not agree to use the term....

S18: [569] Like the term cost of goods sold, the lecturer did not allow to use the term.

S15: [577] Harga pokok per unit is similar to harga pokok produksi ... [581] The English lecturer suggested the price per unit, but in accounting cost of goods sold is used.

The students acknowledged that a discrepancy arose when they preferred to use an English accounting term with which they were familiar, whereas an English lecturer corrected the term based on literal translation appropriateness that he or she assumed. They exemplified the term price per unit as the term suggested by the lecturer, whereas they perceived the cost of goods sold as the standard term used in accounting. However, while they recognized that in accounting price was not commonly used for the term harga, which literally means price, they had trouble in selecting standard English accounting terms for the Indonesian accounting terms they referred to. In the above case, they did not recognize that the appropriate term for harga pokok per unit was 'per unit cost of goods manufactured' which was similar to harga pokok produksi or 'cost of goods manufactured.' One student perceived that it was necessary for the English lecturers to learn to account for the purpose of helping the students learn the terminology. This implied the students' beliefs in the inability of the English lecturers to help them with terminology knowledge unless the lecturers learned accounting. The students' acknowledgment of their learning difficulties with the accounting terminology may bring about implications for interdisciplinary teaching which may be burdensome for the English lecturers. This study provided evidence of the complexity of discussing discipline-specific accounting content in an EFL context where both the students and subject lecturers get difficulties in accessing knowledge written in English. Capability for interdisciplinary teaching might be desired. However, the English lecturers could be encumbered by a difficult task, i.e. learning specialist knowledge which was not the area of their expertise. Apart from rhetorical and genre analysis, the provision of authentic texts of a specific discipline in ESP pedagogy remains burdensome because of the close connection between content and language (see, e.g. Barron, 2002, Northcott \& Brown, 2006; Yin \& Cheung, 1986).

\section{CONCLUSION}

This paper has reported the ESP-EFL students' needs perspectives and needs analysis practices. It has shown that their reports on their present situation analyses (PSA) for their communicative needs indicated that their analyses of their learning needs were intended to achieve their target needs, i.e. conversational skills for social interactions. However, in the EFL context of Indonesia, where English is limitedly used in social interactions, their target needs analysis provided evidence that beyond their primary interest in the conversational skills, they had limited knowledge of their target needs. Their reports on their deficiency in grammatical knowledge, their desire for grammatical feedback and improving speaking fluency, as well as their expectations of a more sequential design for their English courses in relation to excessive grammar provision provided insights not only into the way they wanted to achieve their target needs but also into the type of language exposure they had received. Therefore, in terms of needs analysis practices, the students' PSA in this context provided useful insights into factors that they perceived would strongly affect their achievement of the target situation needs.

The students' analyses of accounting needs also revealed that while they had limited knowledge about workplace accounting needs, they could provide more comprehensive information about their learning experiences either in their specialist courses or ESP courses. They were aware of their deficiency in knowledge of English accounting terminology that was mostly derived from the learning problems they encountered. They identified unfavorable 
learning conditions in their accounting courses and English (ESP) courses that affected their success in the mastery of the terminology.

As the accounting students had insufficient information about their target language needs, this paper has also shown an area that warrants further investigations: accounting students' target communicative tasks and English accounting registers in the workplace accounting practice.

\section{REFERENCE}

Adyawardhani, Y. (2003). Strategic reading process of expository texts: An implication to the teaching of reading. Paper presented at The $51^{\text {st }}$ TEFLIN International Conference. Bandung.

Al-Jamal, D. A., \& Al-Jamal, G. A. (2014). An investigation of the difficulties faced by EFL undergraduates in speaking skill. English Language Teaching, 7(1), 1927.

Bacha, N. N. \& Bahous, R. (2008). Contrasting views of business students' writing needs in an EFL environment. English for Specific Purposes, 27, 7493.

Barron, C. (2002). Problem-solving and EAP: Themes and issues in a collaborative teaching venture. English for Specific Purposes, 22, 297-314.

Belcher, D. (2006). English for Specific Purposes: Teaching to perceived needs and imagined futures in worlds of work, study, and everyday life. TESOL Quarterly, 40(1), 133-156.

Berg, B. L. (2009). Qualitative research methods for the social sciences (Seventh edition). Boston: Pearson Education, Inc.

Bhatia, V. K. (1991). A genre-based approach to ESP materials. World Englishes, 10(2), 153-166.

Boonkit, K. (2010). Enhancing the development of speaking skills for non-native speakers of English. Procedia Social and Behavioural Sciences, 2, 1305-1309.

Braun, V., \& Clarke, V. (2006). Using thematic analysis in psychology. Qualitative research in psychology, 3(2), 77-101.

Brown, C. L. (2007). Supporting English language learners in content-reading. ProQuest Education Journal, 44(1): 32-39.

Chia, H. U., Johnson, R., Chia, H. L., \& Olive, F. (1999). English for college students in Taiwan: A study of perceptions of English needs in a medical context. English for Specific Purposes, 18(2), 107-119.

Coleman, H. (1997). Undergraduate ELT: Where have we been and where are we going? In H. Coleman, T. M. Soedrajat, \& G. Westaway (Eds.), Teaching English to university undergraduates in the Indonesian context: Issues and developments, (pp. 26 - 42). Leeds: University of Leeds, School of Education \& Bandung: Institute Teknologi Bandung.

Cowling, J. D. (2007). Needs analysis: Planning a syllabus for a series of intensive workplace courses at a leading
Japanese company. English for Specific Purposes, 26, 426-442.

Djiwandono, P. I. (2008). A profile of needs and wants of Indonesian learners of English at university level: A snapshot of reality in Asian classrooms. Paper presented at the $6^{\text {th }}$ Asia TEFL International Conference. Bali.

Edwards, N. (2000). Language for business: Effective needs assessment, syllabus design, and materials preparation in a practical ESP case study. English for Specific Purposes, 19, 291-296.

Evans, S. (2012). Designing email tasks for the business English classrooms: Implications from a study of Hong Kong's key industries. English for Specific Purposes, 31, 202-212.

Flowerdew, J., \& Wan, A. (2006). Genre analysis of tax computation letters: How and why tax accountants write the way they do. English for Specific Purposes, 25, 133-153.

Flowerdew, J., \& Wan, A. (2010). The linguistic and the contextual in applied genre analysis: The case of the company audit report. English for Specific Purposes, 29(2), 78-93.

Gimenez, J. C. (2000). Business e-mail communication: Some emerging tendencies in register. English for Specific Purposes, 19, 237-251.

Hamied, F. A. (2005). Policies in higher education: What they mean to TEFL in Indonesia. Paper presented at LIA International Conference. Jakarta.

Harsono, Y. M. (2007). Developing learning materials for specific purposes. TEFLIN Journal, 18(2), 178-188.

Henry, A. (2007). Evaluating language learners' response to web-based, data-driven, genre teaching materials. English for Specific Purposes, 26, 462-484.

Holliday, A. (1995). Assessing language needs within an institutional context: An ethnographic approach. English for Specific Purposes, 14(2), 115-126.

Huda, N. (1999). Language learning and teaching: Issues and trends. Malang: IKIP Malang.

Jackson, J. (2005). An inter-university, cross-disciplinary analysis of business education: Perceptions of business faculty in Hong Kong. English for Specific Purposes, 24, 293-306.

Jubhari, R. (2006). Need analysis of Bahasa Inggris I for first year students at Hasanuddin University. Paper presented at The $54^{\text {th }}$ TEFLIN International Conference. Salatiga.

Kassim, H., \& Ali, F. (2010). English communicative events and skills needed at the workplace: Feedback from the industry. English for Specific Purposes, 29, 168-192.

Krueger, R. A., \& Casey, M. A. (2000). Focus groups: a practical guide for applied research. Thousand Oaks: Sage Publications.

Leech, N. L., \& Onwuegbuzie, A. J. (2007). An array of qualitative data analysis tools: A call for data analysis triangulation. School Psychology Quarterly, 22(4), 557-584. 
Leech, N. L., \& Onwuegbuzie, A. J. (2008). Qualitative data analysis: A compendium of techniques and framework for selection for school psychology research and beyond. School Psychology Quarterly, 23(4), 587-604.

Lehtonen, T., \& Karjalainen, S. (2009). Workplace language needs and university language education - Do they meet? European Journal of Education, 44(3), 411420.

Long, M. H. (2005). Methodological issues in learner needs analysis. In M.H. Long (Eds.), Second language needs analysis (pp. 19-76). Cambridge: Cambridge University Press.

Madya, S. (2003). Designing competency-based TEFL for S1 students to foster professionalism. Paper presented at the NUESP (Network of University ELT Service Providers) National Conference. Jember.

Northcott, J., \& Brown, G. (2006). Legal translator training partnership between teachers of English for legal purposes and legal specialists. English for Specific Purposes, 25, 358-375.

Nunan, D. (2001). Syllabus design. In M. Celce-Murcia (Eds.), Teaching English as a second or foreign language. Boston: Heinle \& Heinle.

Nurweni, A., \& Read, J. (1999). The English vocabulary knowledge of Indonesian university students. English for Specific Purposes, 18(2), 161-175.

Pholsward, R. (1993). The English language needs of Thai computing professional. RELC Journal, 24(1), 86108.

Riyandari, A. (2003). Challenges in implementing competencybased English language teaching at the university level. Paper presented at The $51^{\text {st }}$ TEFLIN International Conference. Bandung.

Rohayati, A., Coleman, H. \& Hardjanto, T. (1997). Needs analysis for materials design. In H. Coleman, T. M. Soedrajat, \& G. Westaway (Eds.), Teaching English to university undergraduates in the Indonesian context: Issues and developments, (pp. 132 - 138). Leeds: University of Leeds, School of Education \& Bandung: Institute Teknologi Bandung.

Sadtono, E. (2005). A concise history of TEFL in Indonesia. Paper presented at The 53rd TEFLIN International Conference. Yogyakarta.

Savignon, S. J. (2007). Beyond communicative language teaching: What's ahead? Journal of Pragmatics, 39, 207-220.

Sayer, P. (2005). An intensive approach to building conversation skills. ELT Journal, 59(1), 14-22.

Sinclair, J. M. (1980). Some implications of discourse analysis for ESP methodology. Applied Linguistics, 1(3), 253261.

Sujana, I. M. (2006). Redesigning teaching reading in ESP contexts to improve academic reading ability and to promote "Learning-how-to-learn." Paper presented at The $54^{\text {th }}$ TEFLIN International Conference. Salatiga.
Swales, J. M. (1986). A genre-based approach to language across the curriculum. In M.L. Tickoo (Eds.), Language across the curriculum (pp. 10-22), Anthology Series 15. Singapore: SEAMEO Regional Language Centre.

Swales, J. M. (1990). Genre analysis: English in academic and research settings. Cambridge: Cambridge University Press.

Swales, J. M. (2004). Research genre: Explorations and applications. Cambridge: Cambridge University Press.

Yayli, D. (2011). From genre awareness to cross-genre awareness: A study in an EFL context. Journal of English for Academic Purposes, 10, 121-129.

Yin, K. M., \& Cheung, D. (1986). Communication skills for engineering undergraduates: Discipline-language integrated approach. In M.L. Tickoo (Eds.), Language across the curriculum, Anthology Series 15. Singapore: SEAMEO Regional Language Centre.

Zhang, Y. (2009). Reading to speak: Integrating oral communication skills. English Teaching Forum, 47(1), 32-34. Retrieved from http://americanenglish.state.gov/ files/ae/resource_files/09-47-1-f.pdf 